\title{
Kajian Hidrodinamika bagi Pengembangan Budidaya Laut di Sekotong, Nusa Tenggara Barat
}

\section{AI DIDIH HENDRIANTI ${ }^{1}$, YESSI NIRWANA KURNIADI ${ }^{1}$, AIDA HERIATI ${ }^{2}$}

\author{
1]urusan Teknik Sipil, Institut Teknologi Nasional, Bandung \\ 2Pusat Penelitian dan Pengembangan Sumber Daya Laut dan Pesisir, \\ Kementerian Kelautan dan Perikanan \\ Email: adhendrianti@gmail.com
}

\begin{abstract}
ABSTRAK
Sekotong adalah salah satu pulau di Indonesia yang berada pada provinsi Nusa Tenggara Barat. Salah satu potensi perairan Sekotong ini adalah usaha budidaya mutiara. Jenis mutiara yang umum dibudidayakan dari spesies Pinctada maxima. Faktor yang mempengaruhi keberhasilan usaha budidaya mutiara salah satunya adalah pemilihan lokasi yang tepat yaitu harus terletak pada perairan yang tenang dan terhindar dari gerakan arus yang besar. Kecepatan arus yang optimal untuk budidaya kerang mutiara berkisar antara $10-25 \mathrm{~cm} /$ detik. Analisis kecepatan arus dan pasang surut dilakukan dengan software MIKE 21. Tujuan dari penelitian ini adalah untuk menganalisis pola hidrodinamika serta mengkaitkannya dengan kondisi perairan Sekotong, NTB apakah baik dijadikan sebagai lokasi budidaya tiram mutiara. Hasil pemodelan dan pengukuran didapat tipe pasang surut campuran cenderung ganda (mixed predominantly semi diurnal) dan hasil pemodelan menunjukkan bahwa lokasi perairan sekotong ini sesuai untuk dijadikan lokasi budidaya mutiara yang ditunjukkan oleh kecepatan arus hasil pemodelan adalah 20,11 cm/detik.
\end{abstract}

Kata kunci: hidrodinamika, budidaya mutiara, arus, pasang surut

\begin{abstract}
Sekotong is one of the islands in Indonesia located in the province of West Nusa Tenggara. One of potential Sekotong waters is pearl farming. The type of pearl is commonly cultivated from the Pinctada maxima species. One of the factors that affect the successfulof pearl farming is the selection of the right location that must lie in the calm waters and must avoid the movement of large currents. The optimal flow rate for pearl cultivation ranges from $10-25 \mathrm{~cm} / \mathrm{sec}$. Analysis of current and tidal velocity is done with MIKE 21 software. The purpose of this research is to analyze hydrodynamics and relate it to the condition of Sekotong waters is West Nusa Tenggara well used as the location cultivation. The modeling and measurement result, there are mixed tidal type tend to be double (mixed predominantly semi diurnal) and the modeling results show that the location of the sekotong waters is suitable for the pearl cultivation location shown by the velocity of modeling current is $20.11 \mathrm{~cm} / \mathrm{sec}$.
\end{abstract}

Keywords: hydrodynamics, cultivation of pearl, currents, tidal 


\section{Pendahuluan}

Secara geografi perairan Sekotong ini berada di Kepulauan Lombok Barat yang masih terkena pengaruh daratan dan lautan sehingga banyak sekali aktifitas di wilayah tersebut baik yang bernilai ekonomis maupun tidak, maka diperlukan suatu pengelolaan untuk dapat memanfaatkan sumberdaya secara maksimal namun tanpa merusak wilayah pesisir tersebut dan tetap mempertimbangkan prinsip keberlanjutan. Penelitian ini lebih menitik beratkan pada salahsatu daya dukung kegiatan budidaya mutiara di Perairan Sekotong, Lombok Barat, Nusa Tenggara Barat. Mutiara yang dibudidayakan di perairan Nusa Tenggara Barat adalah jenis mutiara Pinctada maxima, selain itu ada juga jenis mutiara lain seperti Pinctada margaritifera, Pinctada fucata, Pinctada chemnitzi, Pteria penguin. Beberapa hal penting yang harus diperhatikan untuk budidaya mutiara antara lain adalah budidaya ini harus terletak pada perairan yang tenang dan terlindung dari pengaruh angin musim, gerakan arus dan gelombang yang besar, bebas dari kemungkinan kemungkinan adanya pencemaran baik yang diakibatkan oleh hasil buangan sampah/kotoran kota, maupun buangan industri, bebas dari lalu lintas kapal dan budidaya tidak mengganggu alur pelayaran (Aunurohim, 2014).

\section{TINJAUAN PUSTAKA}

\subsection{Arus}

Arus adalah gerakan air yang mengakibatkan perpindahan horizontal dan vertikal massa air (Sugianto \& ADS, 2007). Budidaya mutiara sangat cocok pada lokasi yang terlindung dari pengaruh arus yang kuat serta pasang surut yang terjadi dapat menggantikan massa air secara total. Kecepatan arus yang optimal untuk budidaya kerang mutiara berkisar antara 10-25 cm/detik (Departemen Kelautan dan Perikanan Republik Indonesia, 2016).

\subsection{Arus Sejajar Pantai}

Arus sejajar pantai atau Longshore Current adalah arus laut yang arahnya sejajar dengan garis pantai. Longshore current terjadi di antara daerah gelombang pecah dan garis pantai, dimana saat gelombang datang membentuk sudut miring $\left(\alpha_{b}>5^{\circ}\right)$ (Triatmodjo, 1999). Arus sejajar pantai mempunyai kecepatan rendah, tetapi sangat mempengaruhi proses-proses litoral transport karena bergerak sepanjang pantai dalam waktu yang lama dan terus menerus selama ada gelombang, sehingga mampu memindahkan sedimen (Faza \& Kurniadi, 2016).

\subsection{Pasang Surut}

Pasang surut adalah fluktuasi (gerakan naik turunnya) muka air laut secara berirama karena adanya gaya tarik bendabenda di langit, terutama bulan dan matahari terhadap massa air laut di bumi (Triatmodjo, 1999). Di perairan-perairan pantai, terutama di teluk-teluk atau di selat-selat yang sempit, gerakan naik turun atau variasi muka air menimbulkan arus yang disebut dengan arus pasang surut, yang menyangkut massa air dalam jumlah sangat besar dan arahnya kurang lebih bolak-balik.

\subsection{Suhu Perairan}

Kerang mutiara akan mengalami pertumbuhan terbaiknya pada daerah yang memiliki iklim tropis karena memiliki perairan yang hangat sepanjang tahun. Suhu yang baik untuk bubidaya kerang mutiara berkisar antara $28-30^{\circ} \mathrm{C}$ (Departemen Kelautan dan Perikanan Republik Indonesia, 2016). 


\subsection{Kecerahan}

Lokasi budidaya kerang mutiara sebaiknya mempunyai kecerahan antara 4,5-6,5 meter, sehingga kedalaman pemeliharaan bias diusahakan antara 6-7 m, sebab biasanya kerang yang dibudidayakan diletakkan di bawah kedalaman atau kecerahan rata-rata (Departemen Kelautan dan Perikanan Republik Indonesia, 2016). Pada Tabel 1 menjelaskan kriteria kesesuaian lokasi untuk budidaya tiram mutiara.

Tabel 1. Kriteria Kesesuaian Lahan Budidaya Kerang Mutiara (Pintcada maxima)

\begin{tabular}{|c|c|c|c|c|c|c|}
\hline No & Parameter & Satuan & Kisaran & Skor & $\begin{array}{l}\text { Bobot } \\
(\%)\end{array}$ & $\begin{array}{l}\text { Nilai } \\
(\mathbf{S} * \mathbf{B})\end{array}$ \\
\hline 1 & $\begin{array}{l}\text { Kepadatan } \\
\text { Fitoplankton }\end{array}$ & $\mathrm{sel} / \mathrm{L}$ & $\begin{array}{c}>15.000 \&<5 * 10^{5} \\
2.000-15.000 \&<5 * 10^{5}-10^{8} \\
<2.000 \&>10^{8}\end{array}$ & $\begin{array}{l}5 \\
3 \\
1\end{array}$ & 30 & $\begin{array}{l}150 \\
90 \\
30\end{array}$ \\
\hline 2 & $\begin{array}{l}\text { Kecepatan } \\
\text { Arus }\end{array}$ & $\mathrm{cm} / \mathrm{dt}$ & $\begin{array}{c}15-25 \\
10-15 \& 25-30 \\
<10 \&>30\end{array}$ & $\begin{array}{l}5 \\
3 \\
1\end{array}$ & 15 & $\begin{array}{l}75 \\
45 \\
15\end{array}$ \\
\hline 3 & $\begin{array}{l}\text { Kedalaman } \\
\text { Perairan }\end{array}$ & meter & $\begin{array}{c}10-20 \\
10-15 \& 25-30 \\
<10 \&>30\end{array}$ & $\begin{array}{l}5 \\
3 \\
1\end{array}$ & 10 & $\begin{array}{l}50 \\
30 \\
10\end{array}$ \\
\hline 4 & $\begin{array}{l}\text { Oksigen } \\
\text { Terlarut }\end{array}$ & $\mathrm{mg} / \mathrm{l}$ & $\begin{array}{l}>6 \\
4-6 \\
<4\end{array}$ & $\begin{array}{l}5 \\
3 \\
1\end{array}$ & 5 & $\begin{array}{c}25 \\
15 \\
5\end{array}$ \\
\hline 5 & Suhu & ${ }^{\circ} \mathrm{C}$ & $\begin{aligned} & 28-30 \\
& 31-32 \\
< & 28 \&>32\end{aligned}$ & $\begin{array}{l}5 \\
3 \\
1\end{array}$ & 5 & $\begin{array}{c}25 \\
15 \\
5\end{array}$ \\
\hline 6 & Salinitas & $\mathrm{ppt}$ & $\begin{array}{c}32 \\
33-35 \\
<32 \&>35\end{array}$ & $\begin{array}{l}5 \\
3 \\
1\end{array}$ & 5 & $\begin{array}{c}25 \\
15 \\
5\end{array}$ \\
\hline 7 & Kecerahan & meter & $\begin{array}{c}4,5-6,5 \\
3,5-4,4 \& 6,6-7,7 \\
<3,5 \&>7,7\end{array}$ & $\begin{array}{l}5 \\
3 \\
1\end{array}$ & 15 & $\begin{array}{l}75 \\
45 \\
15\end{array}$ \\
\hline 8 & $\begin{array}{l}\text { Substrat } \\
\text { Dasar } \\
\text { Perairan }\end{array}$ & & $\begin{array}{c}\text { Berkarang } \\
\text { Berpasir } \\
\text { Pasir Berlumpur }\end{array}$ & $\begin{array}{l}5 \\
3 \\
1\end{array}$ & 10 & $\begin{array}{l}50 \\
30 \\
10\end{array}$ \\
\hline 9 & Fosfat & $\mathrm{mg} / \mathrm{l}$ & $\begin{array}{c}4,5-5,0 \\
5,1-6,5 \\
<4,5 \&>6,5\end{array}$ & $\begin{array}{l}5 \\
3 \\
1\end{array}$ & 5 & $\begin{array}{c}25 \\
15 \\
5\end{array}$ \\
\hline \multicolumn{3}{|c|}{ Total Nilai } & & & 100 & 500 \\
\hline
\end{tabular}

(Sumber: Departemen Kelautan dan Perikanan Republik Indonesia, 2016)

\section{METODE PENELITIAN}

Pemilihan lokasi untuk budidaya mutiara perlu dilakukan penelitian yang detail agar tidak salah mengambil langkah dalam memilih lokasi, sama halnya untuk penelitian kesesuaian perairan Sekotong, Lombok Barat untuk budidaya mutiara. Oleh karena itu diperlukan adanya penelitian dan tinjauan terlebih dahulu sebelum menentukan lokasi budidaya mutiara yang baik. Salah satu hal yang harus diperhatikan adalah kondisi perairan yang akan dijadikan lokasi budidaya, dimana harus terhindar dari gelombang yang besar dan arus 
tidak boleh lebih dari $15-25 \mathrm{~cm} /$ detik, karena untuk budidaya mutiara ini diperlukan perairan yang tenang.

\subsection{Alur Penelitian}

Tahapan pertama yang dimulai adalah merumuskan permasalahan untuk menentukan lokasi budidaya mutiara di Lombok Barat, dilanjutkan dengan studi literatur dan mengumpulkan data-data yang diperlukan. Langkah selanjutnya yaitu membuat pemodelan dengan memasukkan data batimetri, pasang surut dan arus di perairan Sekotong, Lombok Barat ke dalam software MIKE 21. Setelah dimasukkan maka dapat diamati pola hidrodinamika yang terjadi di kawasan tersebut. Langkah selanjutnya adalah melakukan validasi dengan data arus dan pasang surut yang merupakan hasil survey Kementerian Kelautan dan Perikanan. Validasi data arus ini bertujuan untuk memastikan bahwa hasil pemodelan sama dengan kondisi di lapangan, jika hasil validasi tidak sesuai maka dilakukan kalibrasi pada pemodelan sampai hasilnya sesuai, selanjutnya akan didapat output berupa kecepatan arus dan pasang surut di lokasi tinjauan dan memutuskan kesesuain lokasi tersebut untuk budidaya tiram mutiara.

\subsection{Pengumpulan Data Batimetri}

Data batimetri diperoleh dari peta kedalaman laut Dishidros TNI Angkatan Laut seperti yang terlihat pada Gambar 1.

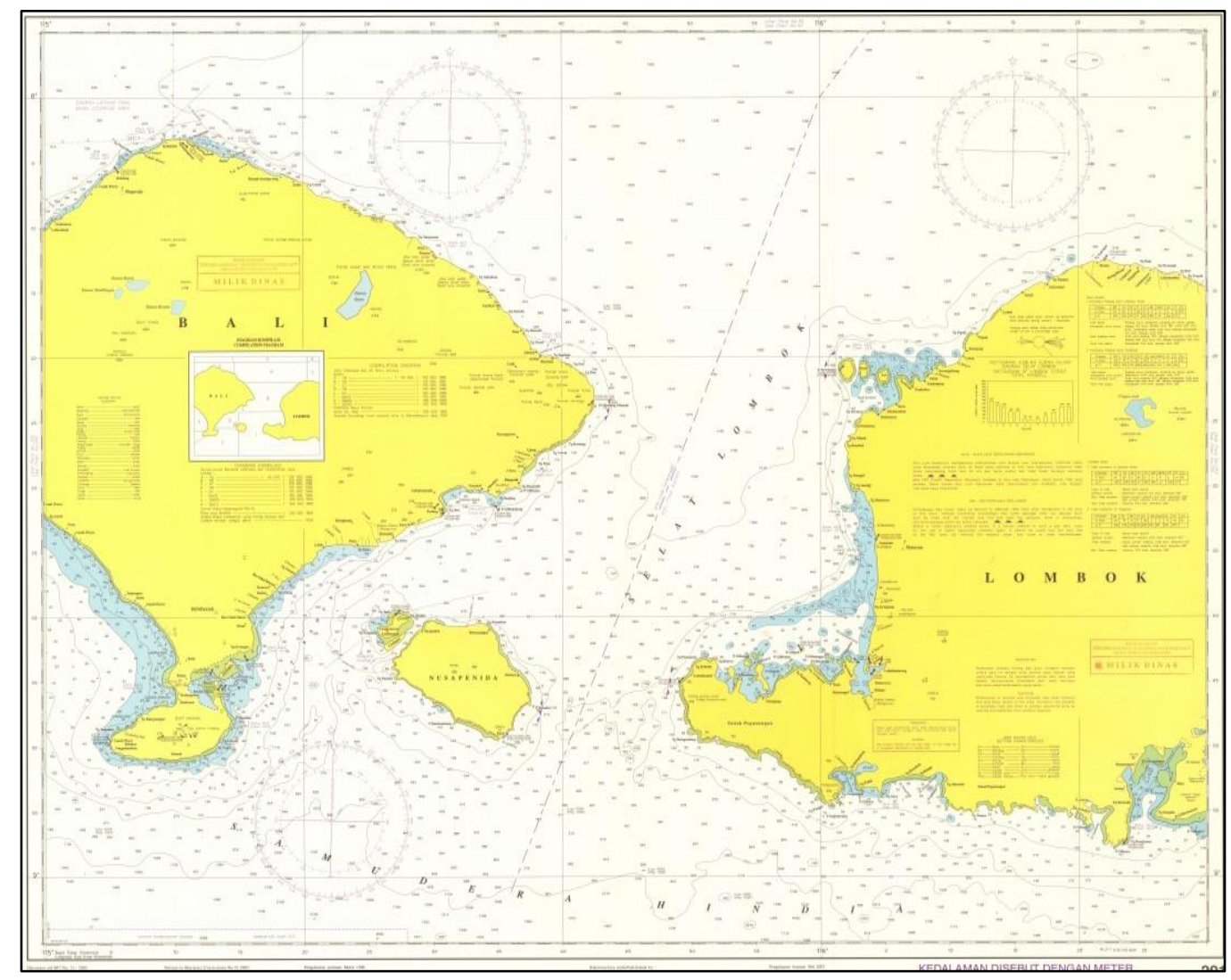

Gambar 1. Peta kedalaman laut

(Sumber: Dishidros TNI Angkatan Laut, 2003)

\subsection{Pasang Surut}

Survey pasang surut di Sekotong, Lombok Barat, alat ukur yang digunakan adalah alat ukur pasut otomatis dengan cara kerja pengukuran berdasarkan tekanan air. Gambaran umum dari pengukuran pasut dengan Tidegauge - Tidemaster - Valeport ditampilkan pada Tabel 2. 
Kajian Hidrodinamika bagi Pengembangan Budidaya Laut di Sekotong, Nusa Tenggara Barat

Tabel 2. Gambaran Umum Pengukuran Pasut dengan Tidemaster

\begin{tabular}{ll}
\hline \multicolumn{1}{c}{ Hal } & \multicolumn{1}{c}{$\begin{array}{c}\text { Keterangan } \\
\text { Alat Ukur }\end{array}$} \\
\hline Lokasi Pemasangan & $\begin{array}{l}\text { Dermaga beton, Balai Budidaya Laut, } \\
\text { Sekotong, Lombok Barat }\end{array}$ \\
\hline Koordinat Pemasangan & $8^{\circ} 44^{\prime} 9,65^{\prime \prime} S, 115^{\circ} 57^{\prime} 55,80^{\prime \prime} \mathrm{E}$ \\
\hline Selang Waktu Pengambilan Data & 15 menit \\
\hline Kondisi perairan/cuaca saat pemasangan & $\begin{array}{l}\text { Cerah, panas, gelombnag tenang, surut } \\
\text { menjelang pasang }\end{array}$ \\
\hline Kondisi Perairan/Cuaca Saat Pengambilan & $\begin{array}{l}\text { Mendung, panas, gelombang tenang, } \\
\text { surut menjelang pasang }\end{array}$ \\
\hline
\end{tabular}

(Sumber: Departemen Kelautan dan Perikanan Republik Indonesia, 2016)

Tipe pasang surut periaran sekotong dan sekitarnya dapat dikategorikan sebagai pasang surut campuran cenderung ganda (mixed predominantly semi diurnal) dengan bilangan Formzhal 1,4 dan nilai pasang mencapai 0,868 m serta surut mencapai $-0,959 \mathrm{~m}$. Tunggang pasang pasut di Sekotong mencapai 1,827 m seperti pada Gambar 2.

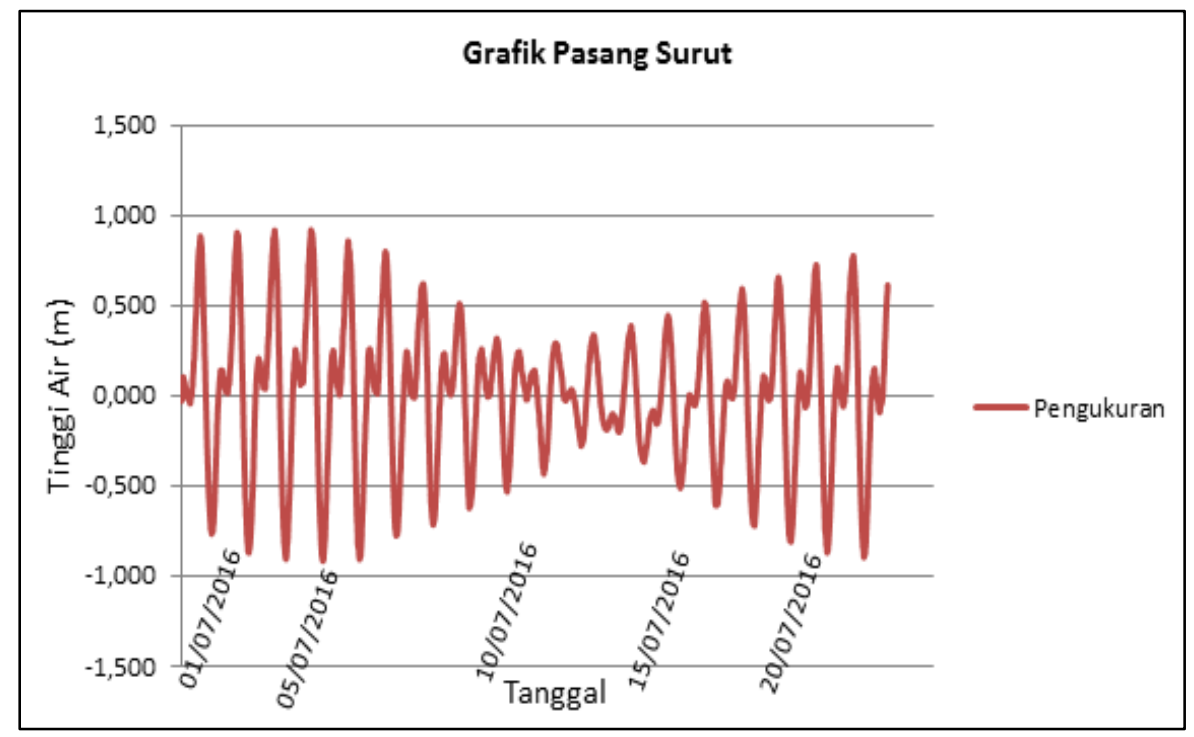

Gambar 2. Plot data pasang surut sekotong

(Sumber: Departemen Kelautan dan Perikanan Republik Indonesia, 2016)

\subsection{Arus}

Pengambilan data arus menggunakan Accoustic Doppler Current Pressure (ADCP) dengan selang waktu 15 menit. Data ADCP yang sudah didapatkan harus diekstrak sehingga data dapat diolah dalam Microsoft Excel. Hasil dari pengolahan data terhadap kondisi arus diperairan Sekotong secara umum tidak terdapat profil dominan yang bergerak ke timur maupun ke barat. Hal tersebut mengindikasikan lemahnya faktor pembangkit arus yang bergerak secara membujur dari barat maupun timur. Hal yang berbeda teridentifikasi pada profil vertikal arus, dimana terdapat perbedaan signifikan antara arus yang bergerak ke arah utara dengan yang bergerak ke arah selatan. Arus kuat yang bergerak ke arah utara (20-30 $\mathrm{cm} /$ detik) secara signifikan mendominasi pola arus di wilayah ini. Arus dimodelkan pada 3 titik. Titik pertama pada koordinat $8^{\circ} 44^{\prime} 9,5^{\prime \prime}$; ; $115^{\circ} 52^{\prime} 55,50 " E$ titik kedua pada koordinat 8०44'9,65"S; $115^{\circ} 57^{\prime} 55,80 " \mathrm{E}$ dan titik ketiga pada koordinat 844'9,65"S; $115^{\circ} 5^{\prime} 55,50^{\prime \prime E}$ terlihat pada Gambar 3. 


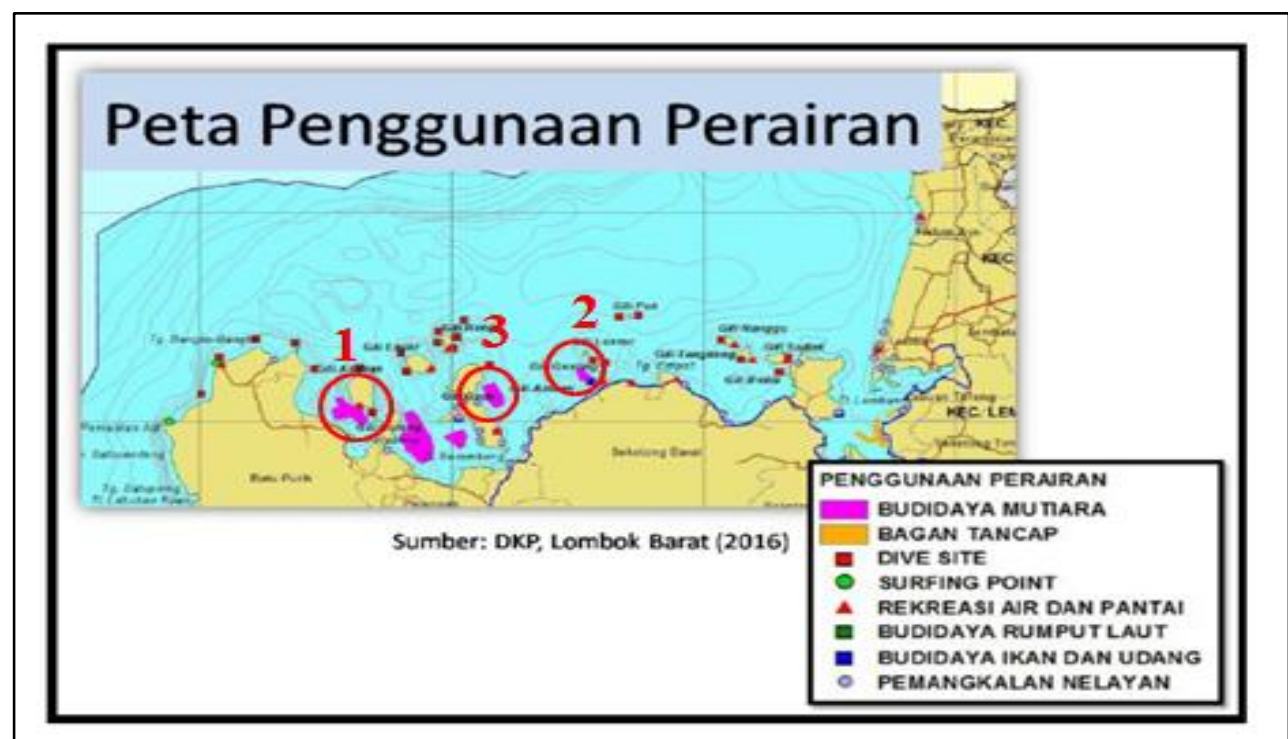

Gambar 3. Titik pemodelan arus

(Sumber: Departemen Kelautan dan Perikanan Republik Indonesia, 2016)

\subsection{Hasil Input Batimetri}

\section{PEMBahasan}

Peta didigitasi untuk mendapatkan data batimetri dengan cara rectangular grid dengan grid $67 * 56$ dengan jarak antar grid $0,45 \mathrm{~cm}$ di peta sebanding dengan jarak antar grid $900 \mathrm{~m}$ di lapangan. Digitasi dimulai pada koordinat $8^{\circ} 20^{\prime} 00^{\prime \prime S}$; $115^{\circ} 35^{\prime} 00^{\prime \prime E}$ sampai pada koordinat $8^{\circ} 45^{\prime} 60^{\prime \prime S} ; 116^{\circ} 5^{\prime} 55,80^{\prime \prime E}$. Data batimetri yang sudah didigitasi dari peta yang didapatkan dari Kementerian Kelautan dan Perikanan di-input ke software MIKE 21 sehingga terbentuk kontur yang ditandai dengan berbagai warna sebagai tanda kedalaman yang terbentuk (Gambar 4).

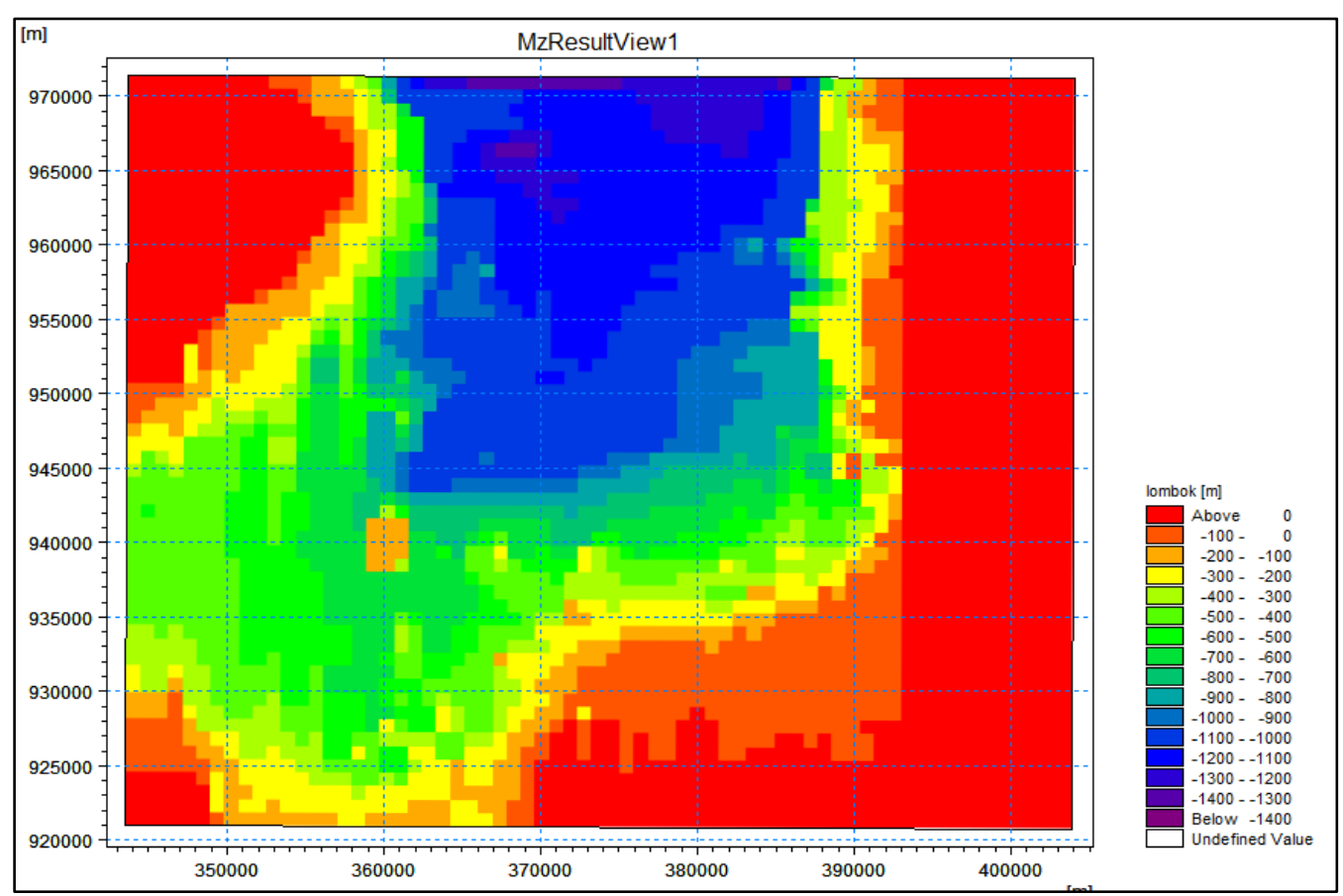

Gambar 4. Hasil input data batimetri 


\subsection{Hasil Pemodelan Pasang Surut}

Percobaan dalam pemodelan ini dilakukan setiap 900 detik dengan banyaknya percobaan sebanyak 480 kali yang yang dimulai pada tanggal 01 Juli 2016 pada koordinat $8^{\circ} 44^{\prime} 9,65 " S$; $115^{\circ} 57^{\prime} 55,80$ "E. Hasil Pemodelan menunjukkan tipe pasang surut periaran sekotong dan sekitarnya dapat dikategorikan sebagai pasang surut campuran cenderung ganda (mixed predominantly semi diurna) dengan bilangan Formzhal 1,4. Nilai pasang mencapai 0,9153 m serta surut mencapai $-1,01141 \mathrm{~m}$. Tunggang pasang pasut mencapai $\sim 2,016368 \mathrm{~m}$. Hal ini menunjukan jika hasil pemodelan sesuai dengan hasil pengukuran di lokasi perairan Sekotong (Gambar 5).

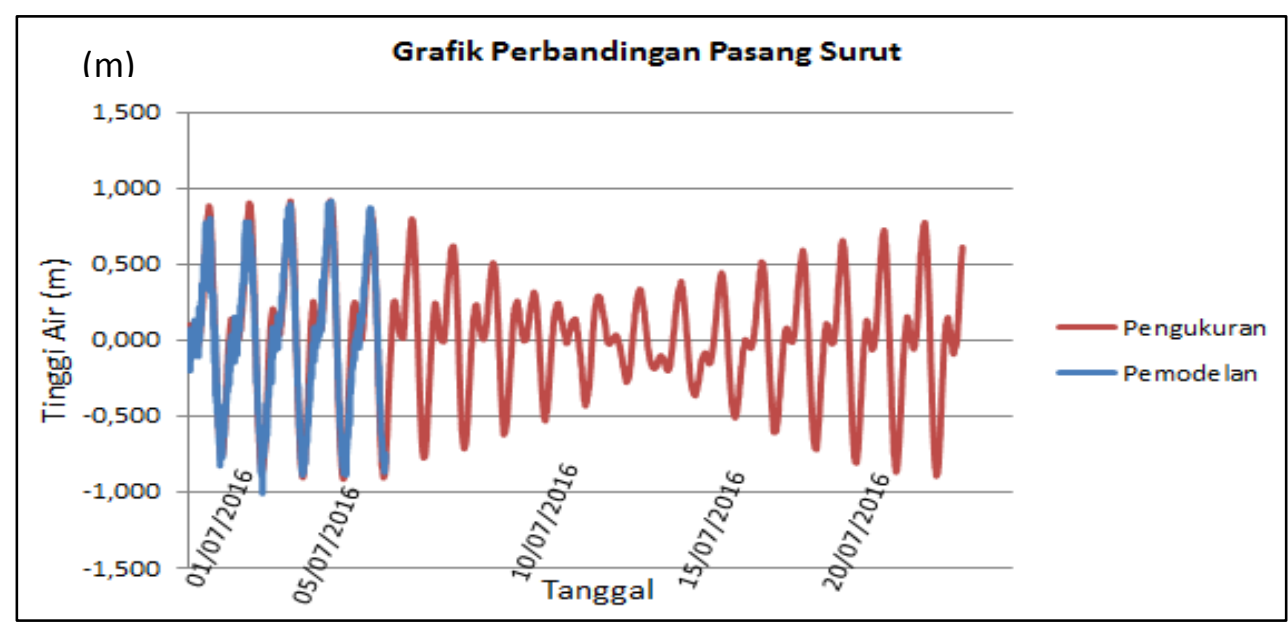

Gambar 5. Perbandingan pasang surut pengukuran dan pemodelan

\subsection{Hasil Pemodelan Arus}

Percobaan dalam pemodelan ini dilakukan setiap 900 detik dengan banyaknya percobaan sebanyak 480 kali yang yang dimulai pada tanggal 01 Juli 2016 jam 12.00 pada beberapa koordinat. Gambar 6, Gambar 7, dan Gambar 8 menunjukkan perbandingan arus hasil pemodelan dan pegukuran, dengan kecepatan arus hasil pemodelan pada titik 1 sebesar 23,747 cm/detik (Gambar 6), pada titik ke 2 menunjukkan hasil kecepatan arus pemodelan sebesar 14,96 cm/detik (Gambar 7), dan pada titik ke 3 menunjukkan kecepatan arus pemodelan sebesar 23,467 cm/detik (Gambar 8).

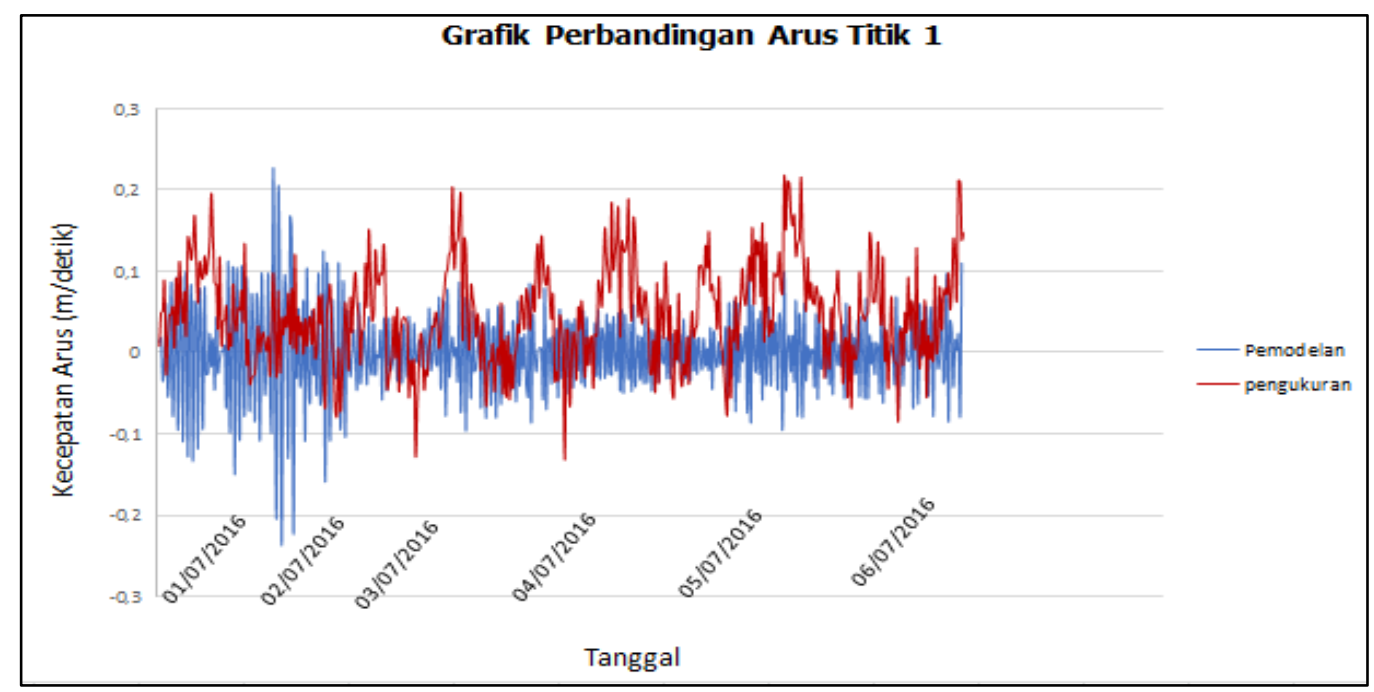

Gambar 6. Perbandingan arus pemodelan dan pengukuran pada titik 1 


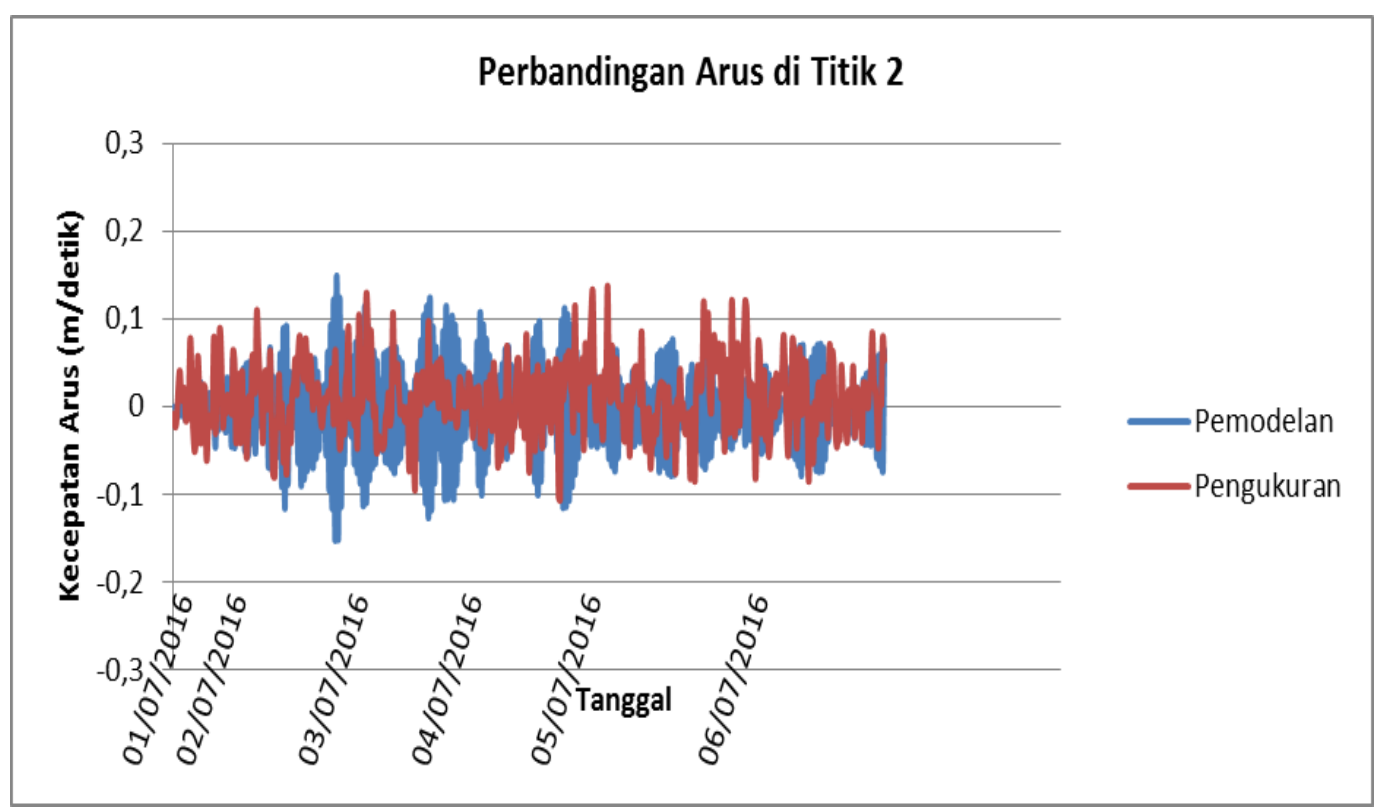

Gambar 7. Perbandingan arus pemodelan dan pengukuran pada titik 2

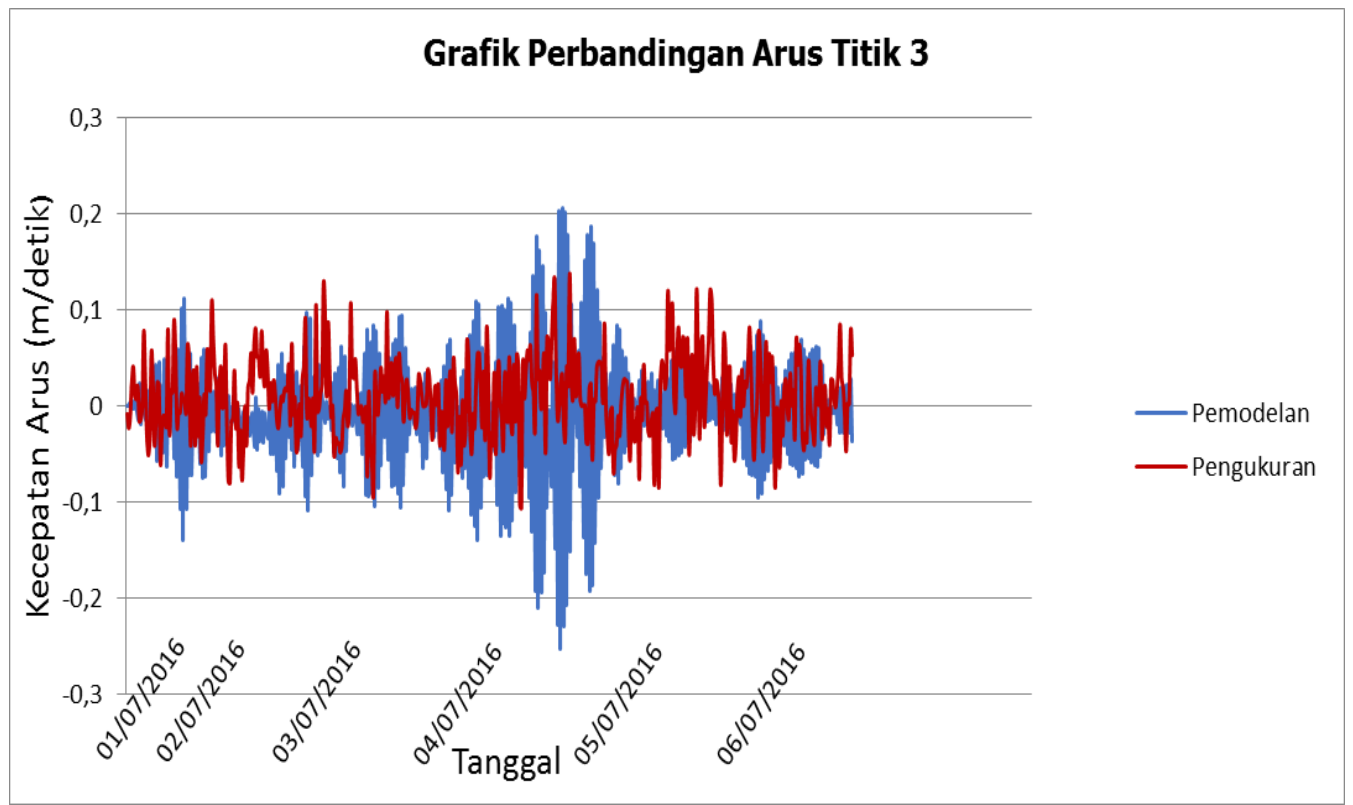

Gambar 8. Perbandingan arus pemodelan dan pengukuran pada titik 3 


\subsection{Pasang Surut Purnama}

Pasang surut mempengaruhi kecepatan dan pola arus, pada saat air menjelang pasang, ketinggian muka air laut 0,087 $\mathrm{m}$ di atas muka air rerata dan pola sirkulasi arus bergerak dominan dari arah utara ke selatan dan barat daya dan kecepatan arus mencapai 10-16 $\mathrm{cm} /$ detik. Pada saat air pasang, ketinggian muka air mencapai 0,915 $\mathrm{m}$ di atas muka air rerata, pola arus bergerak dari arah timur laut ke arah barat dan barat daya dengan kecepatan arus mencapai 15-21 cm/detik seperti pada Gambar 9.

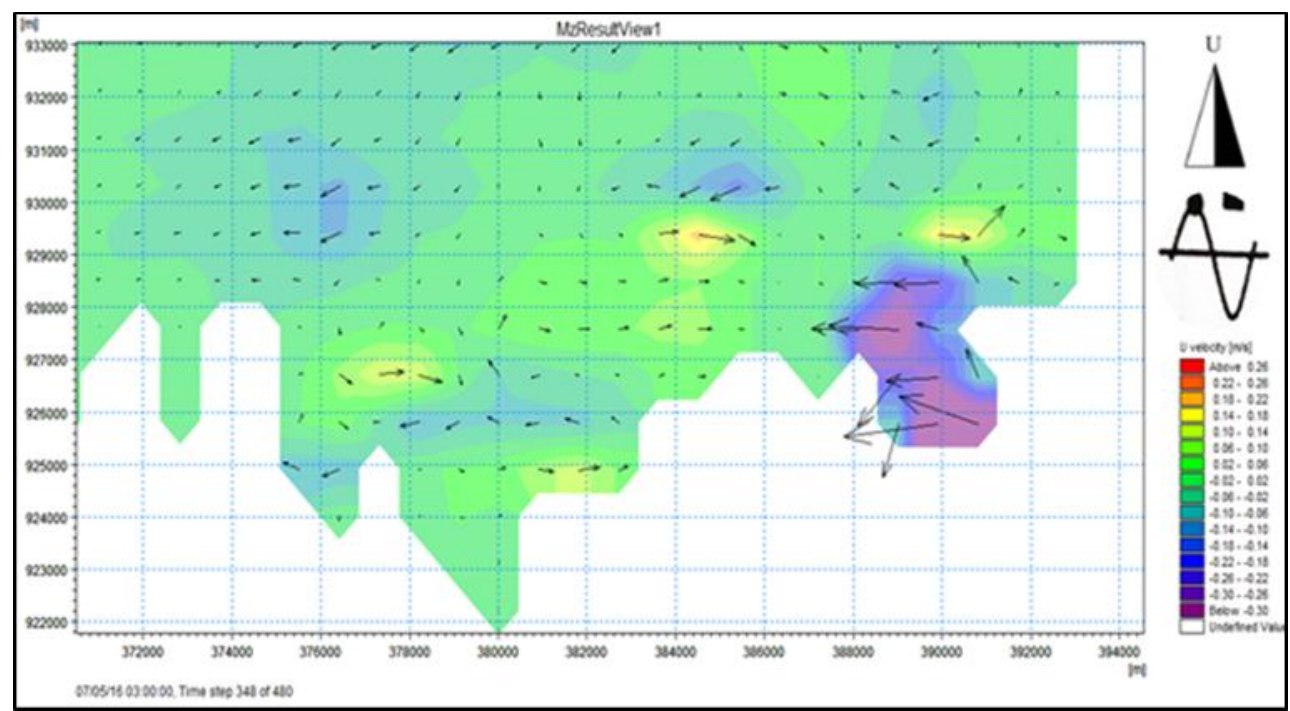

Gambar 9. Pola arus ketika pasang

\subsection{Pasang Surut Perbani}

Pada saat air menjelang surut, ketinggian muka air mencapai $0,148 \mathrm{~m}$ pola arus bergerak dari arah utara ke arah selatan dengan kecepatan arus mencapai $13-15 \mathrm{~cm} /$ detik. Pada saat air surut yaitu muka air pada ketinggian $-1,011 \mathrm{~m}$ di bawah muka air laut rerata pola arus dominan bergerak dari arah selatan ke utara dan dari timur ke arah barat dengan kecepatan arus sampa $10-12 \mathrm{~cm} /$ detik (Gambar 10).

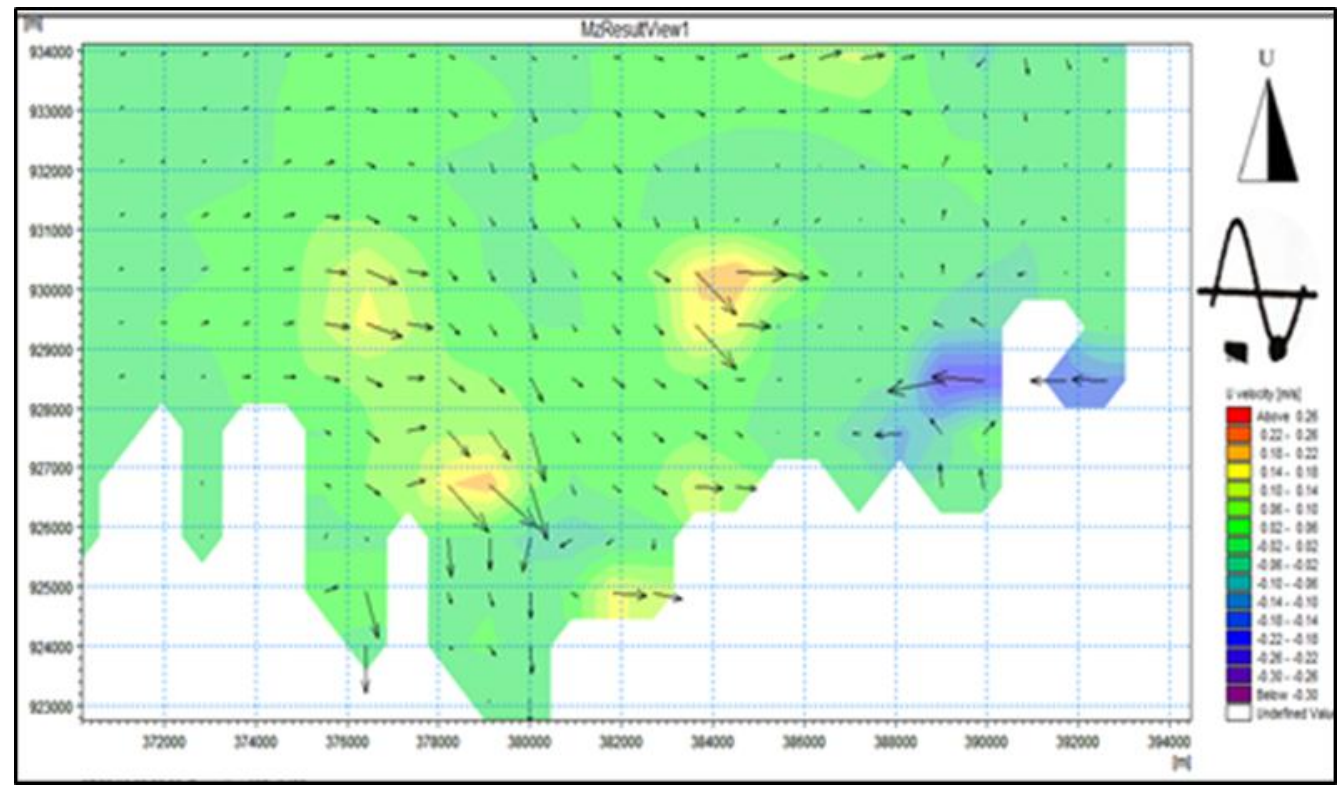

Gambar 10. Pola arus ketika surut 


\subsection{Sebaran Elevasi Muka Air Laut dan Pola Arus}

Pola Arus pengukuran terhadap kedalaman menggunakan ADCP (Accoustic Doppler Current Pressure) di lokasi tinjauan dari tanggal 21 Juni 2017 sampai 21 Juli 2017 dengan selang waktu 15 menit terlihat kecepatan arus arah $\mathrm{U}$ dan arah $\mathrm{V}$ semakin ke permukaan kecepatan arus semakin besar, karena kecepatan arus di permukaan dipengaruhi oleh angin seperti terlihat pada Gambar 11 dan Gambar 12.

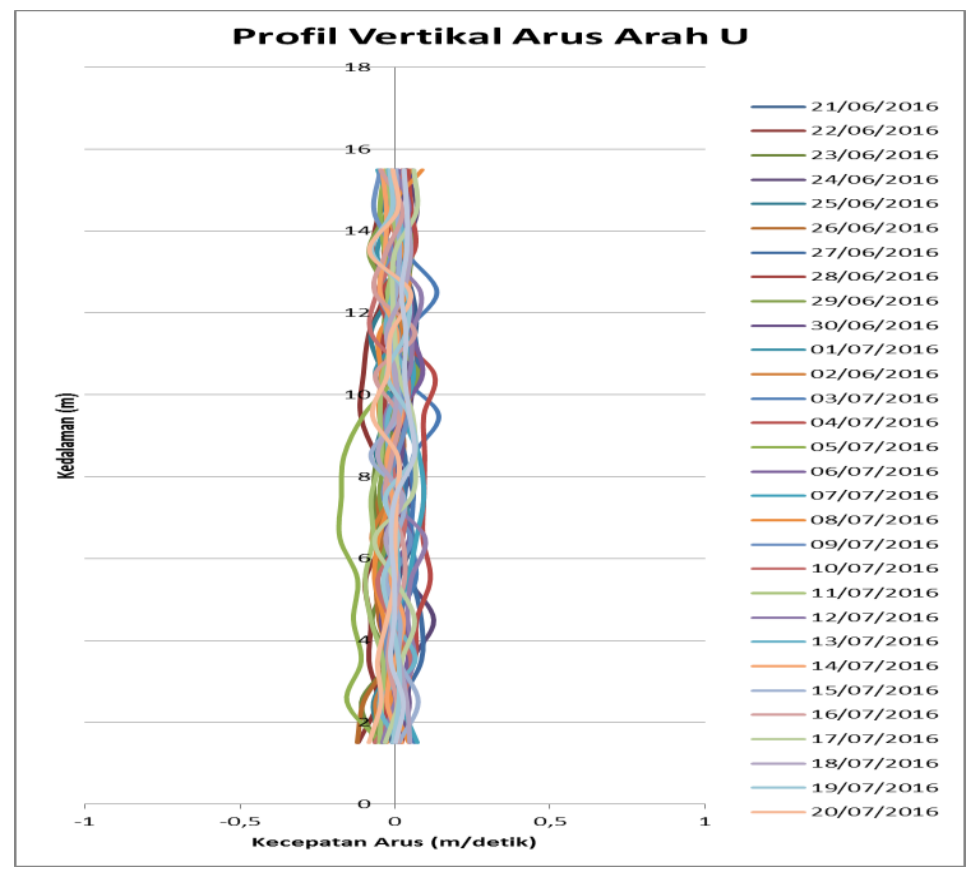

Gambar 11. Profil arusarah U

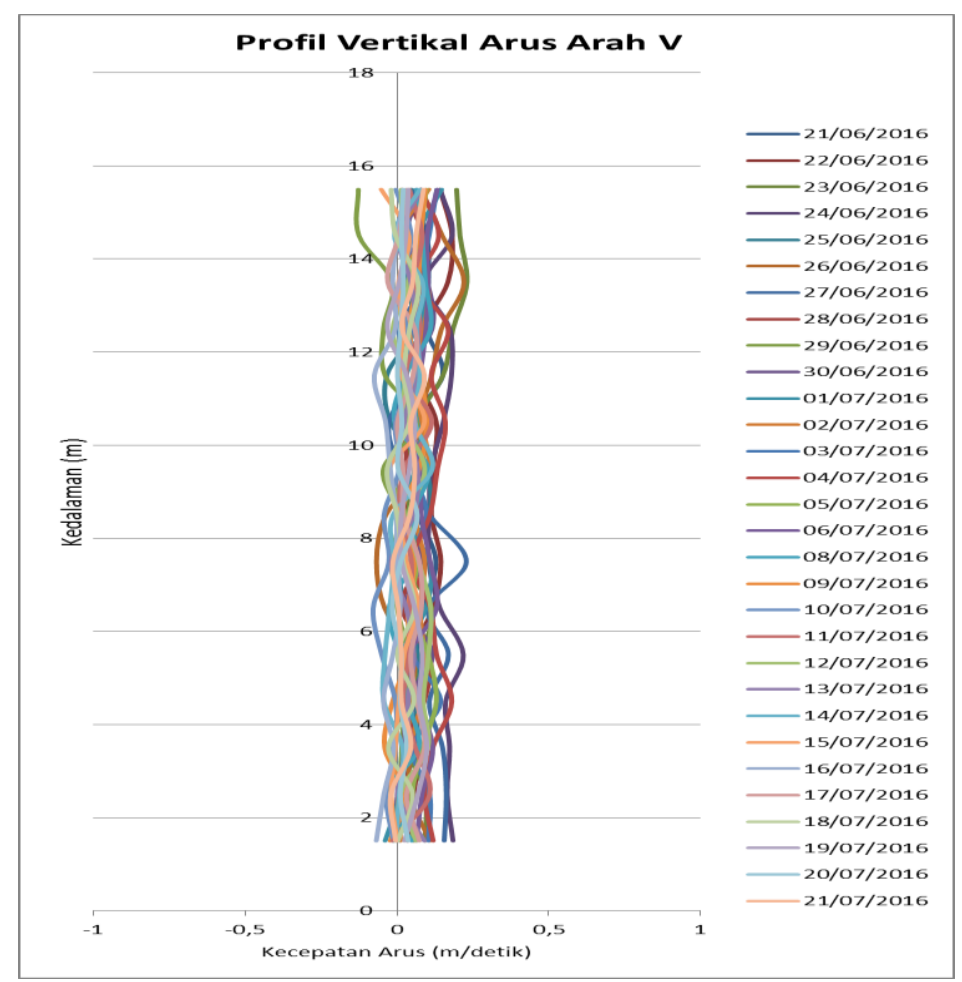

Gambar 12. Profil arus arah $\mathbf{V}$ 


\subsection{Kesimpulan}

\section{KESIMPULAN DAN SARAN}

Dari hasil penelitian, kesimpulan yang diambil adalah:

1. Hasil pemodelan pasang surut menunjukan jika tipe pasang surut hasil pemodelan dan tipe pasang surut hasil pengukuran sesuai, dengan tipe pasang surut campuran cenderung ganda (Mixed predominantly semi diurna), nilai pasang 0,9153 $\mathrm{m}$ serta surut mencapai $-1,01141 \mathrm{~m}$. Tunggang pasang pasut mencapai $\sim 2,016368 \mathrm{~m}$.

2. Hasil pemodelan arus yang ditinjau dari beberapa titik diperoleh kecepetan arus ratarata $20,72 \mathrm{~cm} /$ detik

3. Perairan Sekotong cocok untuk dijadikan lokasi budidaya tiram mutiara, dengan skor 5 yang menunjukkan "baik" (Tabel 1).

\subsection{Saran}

Saran untuk penelitian selanjutnya adalah:

1. Gunakan data batimetri dengan jarak antar grid tidak terlalu jauh.

2. Mempertimbangkan sedimentasi pada penelitian selanjutnya karena kecerahan perairan menjadi salah satu faktor penting juga untuk kesesuaian lokasi budidaya mutiara.

3. Memeriksa stabilitas model dengan waktu pemodelan yang lebih lama.

\section{UCAPAN TERIMAKASIH}

Puji serta Syukur kepada Allah SWT dan terimakasih kepada:

1. Pusat Peneletian dan Pengembangan Sumberdaya Laut dan Pesisir (P3SDLP).

2. Badan Penelitian dan Pengembangan Kelautan Perikanan.

3. Kementerian Kelautan dan Perikanan.

\section{DAFTAR RUJUKAN}

Aunurohim, F. d. (2014). Kajian Komposisi Fitoplankton dab Hubungannya dengan Lokasi Budidaya Kerang Mutiara (Pinctada maxima) di Perairan Sekotong. TEKNIK POMITS, $3(2)$, 93-98.

Departemen Kelautan dan Perikanan Republik Indonesia. (2016). Kajian Kesesuaian Daya Dukung Wilayah Pesisir Bagi Pengembangan Budidaya Laut di Sekotong, Lombok Barat, Nusa Tenggara Barat. Jakarta: Departemen Kelautan dan Perikanan.

Dishidros TNI Angkatan Laut. (2003). Peta Batimetri Selat Lombok. Jakarta.

Faza, L. H., \& Kurniadi, Y. N. (2016). Desain Bangunan Pelindung Pantai Sebagai Penanggulangan Abrasi di Kawasan Pantai Ujung Jabung Provinsi Jambi. Reka Racana, 2(2), 1-12.

Sugianto, D. N., \& ADS, A. (2007). Studi Pola Sirkulasi Arus Laut di Perairan Pantai Provinsi Sumatera Barat. Ilmu Kelautan, 12 (2), 79 - 92.

Triatmodjo, B. (1999). Teknik Pantai. Yogyakarta: Beta Office. 